\title{
Churches claiming a right to the city? Lived urbanisms in the City of Tshwane
}

\begin{tabular}{|c|c|}
\hline $\begin{array}{l}\text { Authors: } \\
\text { Michael Ribbe } \\
\text { Stephan F. de }\end{array}$ & $\begin{array}{l}\mathrm{ns}^{1,2,3} \\
\text { Beer }^{2,3} \text { (D) }\end{array}$ \\
\hline \multicolumn{2}{|c|}{$\begin{array}{l}\text { Affiliations: } \\
{ }^{1} \text { Institute for Urban Ministr } \\
\text { Resonate Global Mission, } \\
\text { South Africa }\end{array}$} \\
\hline \multicolumn{2}{|c|}{$\begin{array}{l}{ }^{2} \text { Centre for Contextual } \\
\text { Ministry, Faculty of Theology, } \\
\text { University of Pretoria, } \\
\text { South Africa }\end{array}$} \\
\hline \multicolumn{2}{|c|}{$\begin{array}{l}{ }^{3} \text { Department of Practical } \\
\text { Theology, Faculty of } \\
\text { Theology, University of } \\
\text { Pretoria, South Africa }\end{array}$} \\
\hline \multicolumn{2}{|c|}{$\begin{array}{l}\text { Research Project } \\
\text { Registration: } \\
\text { Project Leader: S.F. de Beer } \\
\text { Project Number: } 86233689\end{array}$} \\
\hline \multicolumn{2}{|c|}{$\begin{array}{l}\text { Description: } \\
\text { This research is part of th } \\
\text { research project, 'Social } \\
\text { Justice and Reconciliation } \\
\text { which is directed by Dr } \\
\text { Stephan de Beer, Director } \\
\text { the Centre for Contextual } \\
\text { Ministry and member of } \\
\text { Department of Practical } \\
\text { Theology, Faculty of } \\
\text { Theology, University of } \\
\text { Pretoria. }\end{array}$} \\
\hline \multicolumn{2}{|c|}{$\begin{array}{l}\text { Corresponding author: } \\
\text { Michael Ribbens, } \\
\text { mribbens@crcna.org }\end{array}$} \\
\hline \multicolumn{2}{|c|}{$\begin{array}{l}\text { Dates: } \\
\text { Received: } 05 \text { June } 2017 \\
\text { Accepted: } 23 \text { Aug. } 2017 \\
\text { Published: } 27 \text { Nov. } 2017\end{array}$} \\
\hline \multicolumn{2}{|c|}{$\begin{array}{l}\text { How to cite this article: } \\
\text { Ribbens, M. \& De Beer, S.F., } \\
2017, \text { 'Churches claiming a } \\
\text { right to the city? Lived } \\
\text { urbanisms in the City of } \\
\text { Tshwane', HTS Teologiese } \\
\text { Studies/Theological Studies } \\
73(3), \text { a4690. https://doi. } \\
\text { org/10.4102/hts.v73i3.4690 }\end{array}$} \\
\hline \multirow[b]{2}{*}{ 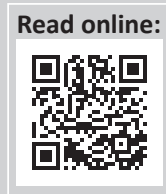 } & \\
\hline & $\begin{array}{l}\text { Scan this QR } \\
\text { code with your } \\
\text { smart phone or } \\
\text { mobile device } \\
\text { to read online. }\end{array}$ \\
\hline
\end{tabular}

This article sets out to describe how churches have responded and continue to respond to fastchanging urban environments in Pretoria Central and Mamelodi East, animating Henri Lefebvre's sociological perspective of citadins or urban inhabitants. We make tentative interpretations and offer critical appreciation. Churches, which were historically separated from the city centre, now directly participate in claiming a right to the city. With necessary fluidity, churches express lived African urbanisms through informality, place-making, spatial innovation and everyday rituals. Though not exhaustive, the article focuses on rituals shared among historic urban Christians and contemporary African urban Christians, namely prayer, listening to the Bible and worship. These rituals, when combined with the churches' spatial innovation, to a certain degree contribute to place-making.

\section{Introduction}

In this article we explore initial findings on how churches in two distinct and yet inextricable regions (Pretoria Central and Mamelodi East) of the City of Tshwane, South Africa, respond to urban change. Our aim is to give a fair presentation of the local churches' enduring presence, raise critical questions and offer insights on the extent to which the churches' inhabitation and practiced rituals address urban vulnerabilities and contribute to place-making amidst urban change.

Our co-research endeavour applied a transdisciplinary approach to engage community and church members from the two regions of study. We merged perspectives from social sciences and theology into a qualitative research methodology and structured the research around the contextual praxis cycle of Holland and Henriot (1983). The participating church and community members refined the generative research questions, unearthed local knowledges and coconstructed a well-rounded understanding of the particular contexts while exploring specific expressions of religious innovation and competition. In an effort to cultivate existing knowledges and inspire new learning with and for the communities, we facilitated participatory processes and spaces through mapping, focus groups and World Cafés. The World Cafés put into effect open space technology to limit potential hierarchies and foster full participation (Steier, Brown \& Mesquita da Silva 2015). These methods were supplemented with literature study, conceptual analysis and surveys, and yet we realise that we retrieved only glimpses into the two regions.

This article interacts with our findings, considers the urbanising context of the City of Tshwane historically against the backdrop of an urbanising African continent and examines the 'lived urbanisms' of local churches, as they unintentionally give expression to Henri Lefebvre's 'right to the city' (cf. Pieterse \& Simone 2013). Or, are they?

\section{Historical background: Negotiation, segregation, apartheid and urbanisation} \section{Early development}

The undulating terrain, freshwater sources and favourable climate around the contemporary city of study attracted human migrations and settlements throughout history. The Sotho-Tswana peoples cultivated social and economic development and established effective trade networks for iron implements, copper ornaments and ivory (Krüger 2003:84; Okihiro 1973). A series of raids and wars

Copyright: ㄷ 2017. The Authors. Licensee: AOSIS. This work is licensed under the Creative Commons Attribution License.

Note: This article forms part of a collaborative research project entitled 'Religious innovation and competition amidst urban social change: a Pretoria case study'. The project was funded by the Templeton Foundation as part of an African-wide enquiry on 'Christianity and social change in contemporary Africa'.

The project is also a sub-theme of the 'Faith in the City' research project, hosted by the Centre for Contextual Ministry in the Faculty of Theology, University of Pretoria. 
known as the Difaqane, or hammering, destroyed entire communities in 2 years, 1822-1824 (Lye 1967:130). During this time, the migratory leader, Mzilikazi, of the Ndebele people settled on both sides of the middle Vaal River in 1823 (Rasmussen 1976:59-62) only to then establish an array of villages at the headwaters of the Apies, Sand and Oori Rivers in mid-1827 (Rasmussen 1976:65). Mzilikazi initiated contact with white people in 1829 to negotiate economic opportunities, military advantage and make a deal with missionaries to reside at his kraal and mediate relations with other white people (Lye 1969:93-94). Even though Mzilikazi invited white merchants and missionaries, no Christian missionary work of any lasting significance was done, and yet:

in principle, the area had been opened for European cultural, military, trade and religious expansion, which would come with the British and their rivals, the Voortrekkers from the Cape Colony. (Krüger 2003:85)

\section{Becoming Pretoria}

The Voortrekkers differed from other white people in that they penetrated territory with commando tactical units, did not seek permission from indigenous rule and acted as if they meant to stay with their large numbers (Lye 1969:94). The Voortrekkers increasingly became disgruntled with British attempts to anglicise Cape society and the church. From 1834 onwards, thousands of white frontier farmers braved northwards with their families and large numbers of mixed race and black servants to escape British power (Krüger 2003:128) until they reached Mzilikazi's land and were routed by the Ndebele people in 1836 (Lye 1969:94). The Voortrekkers battled for over a year to expulse Mzilikazi from the territory in November 1837 (Lye 1969:94). The vacated territory became contested space for a 'triple power struggle - black African, British and Voortrekker (Boer, Afrikaner) - that would largely determine the history of the future Pretoria' (Krüger 2003:86). The Voortrekkers saw themselves as liberators of all African inhabitants from Ndebele oppression, conflated black people with the heathen of the Old Testament and were therefore justified to treat black people as vassals in the Transvaal territory (Krüger 2003:86; Okihiro 1973:108). Once the land on Elandspoort farm along the Apies River was chosen in 1842, the nucleus of permanent white residents cultivated the place and incorporated new Pretoria town in 1855 (Krüger 2003:86).

For a thorough civil-religious history of Pretoria's transition from a frontier town to the major metropolis known as the City of Tswhane and its interrelationship with local Reformed religion, Cobus Krüger's extensive work Sweeping Whirlwinds offers valuable insights. For the purposes of this article, we lean heavily on his work to succinctly capture in several paragraphs what he addresses in three chapters (Krüger 2003:124-265).

\section{Church town, segregated city}

In 1853 Marthinus Wessel Pretorious set out to build a new town and dreamed of a capital in the centre of the Voortrekker republic, but there was already an entrenched pattern Reformed parishes became towns (Krüger 2003:129-130). So it took a successful petition from the Nederduitsch Hervormde on 07 June 1854 to establish Pretoria Philadelphia (Pretorius Brotherhood) and then by an act of the Volksraad (parliament) on 16 November 1855, 'Pretoria' was officially named (Krüger 2003:130). The naming and ties to heroism pursued ideal unity among the Voortrekkers, which was not and would not be extended to include any other group (Krüger 2003:130).

The Voortrekker world view influenced town development, architecture and residential separation. The first church was designed to be at the elevated centre of Pretoria. And from there, a grid of perfectly rectangular blocks and main streets crossed at Church Square and expressed an orderly cosmos and ideals of urban place-making (Jordaan 1989; Krüger 2003:133). There was an immediate quandary because permanent urban African presence happened concurrently with white counterparts (Krüger 2003:136). African servants also made the Great Trek and grew up on the Voortrekker farms, now becoming urban space. These African inhabitants along with the Tswana and Pedi peoples formed the basis of the African population gravitating to Pretoria. The Voortrekker political-religious ideologies attempted to control African presence and already on 18 June 1855, legislation barred all non-whites from becoming citizens and owning property (Krüger 2003:136). The Berlin Mission Society could begin a mission station, but only on the allotted site known as Schoolplaats which 'was to the northwest and just outside the boundaries of town' (Krüger 2003:137138 italics original), becoming the first African township adjacent to white Pretoria under strict control. The permanent expression of control for urban space and the churches' participation in white dominance was affixed already by 1895 when municipal regulations prohibited Africans from walking on sidewalks and made it compulsory for African men to carry passes at all times (Krüger 2003:149).

\section{Imperial city, apartheid city}

Pretoria fell to the British troops in June 1900, became the capital of the self-governing Transvaal in 1907 and was established as the administrative capital of the Union of South Africa in 1910 (Krüger 2003:168-169). The imperialist hand and functionalist approach attempted to protect white labour force while also keeping a compliant African workforce as a labour reservoir (Krüger 2003:173). The Natives (Urban Areas) Act of 1923 enforced full-fledged separatist ideology: 'urban areas were regarded as created by whites for whites' (Krüger 2003:176). Group areas legislation persisted and especially intensified through the 1940s to 1960s. The black majority population would have no rights to land ownership within white urban areas and their daily movement would be policed by the pass system (Krüger 2003:176).

By policing African Influx, the centres of production and white residential areas were protected. Increasingly, the white urban sprawl pushed black people farther from the city centre, solidifying political, social, economic and spatial dominance, and yet the African population continued to migrate towards Pretoria. In the 1930s, Atteridgeville became the first municipally constructed, controlled and administered black location in 
Pretoria, which brought in its wake a huge process of forced removals and resettlement, becoming the brutal pattern of Pretoria's spatial reorientation over the next five decades (Krüger 2003:190). In 1940, African residents in Marabastad were forced to Atteridgeville, becoming a pattern of dominance and forced subservience (Krüger 2003:190). On the eve of the 1948 election, Dr D. F. Malan's reactionary politics declared apartheid to be the structural and political solution for South Africa (Krüger 2003:187). The die was cast for Pretoria to be the 'citadel of white, Afrikaner supremacy, the seat of bureaucracy, the centre of control and censorship in its myriad forms, the heart of the apartheid order' up until the 1990s (Krüger 2003:92).

\section{(Post)apartheid city, City of Tshwane}

As we begin to hone in on our contemporary situation and the particular regions of our comparative study, we have to bear in mind that the systematic segregation by race over many decades built a 'bastardized city structure' and a prototype Apartheid city (Christopher 1983, 1987; Davies 1981; Mphahlele 1959; Thomlinson 1990). Since 1994 the urban landscape of the city has changed considerably in some ways, but - in essence - it could indeed be asked if the apartheid city has been fully dismantled.

Fassil Demissie (2007) and others rightly declare and call for scholarly intervention because the persistent residual effects from imperial legacies and postcolonial predicaments are in the very spatial and social structures of our African cities. The reconfiguration and remaking of urban worlds within Africa must take place according to local identities and African forms of urbanity (Demissie 2007:1-2). One of those residual manifestations is naming - names of buildings, streets, landmarks, sections and of the city itself. To begin to live into the post-apartheid era, government reform and municipality authority officially changed Pretoria to the City of Tshwane, replacing numerous pre-existing local authorities with one greater metropolitan municipality in 2000 (Mabin 2015).

The early involvement of Christianity in the life of the city took on manipulative forms: negotiation, justification for forced separation and dominance. This article explores the continuity of Christian presence and provides initial insights on the contemporary expressions of Christianity in the urban context of study. The historical background of transitioning from a church town to the City Tshwane sets the stage for us to now interact with urban perspectives for application in our context.

\section{Sub-Saharan Africa's confluence: Urbanisation and Christianity}

\section{African urban explosions}

Every day around the world more and more people inmigrate and inhabit the city. The rapidity and scale of the urban transition is remarkable, especially throughout Africa. According to the United Nations' forecasted urbanisation rate, the population of African urban inhabitants will more than double between 2000 and 2030, increasing from 294 million to 742 million and climbing towards 1.26 billion by
2050 (UNFPA 2007:8; UN-HABITAT 2014:23). Of the 100 fastest growing cities in the world, $25 \%$ are African and already by 2011, the continent hosted 52 cities exceeding 1 million inhabitants (UN-HABITAT 2014:23). Of these 52 cities, 4 are strikingly in the Gauteng-City region of South Africa - Johannesburg, the City of Tshwane, Ekurhuleni and Sedibeng Municipality - making it one of fastest growing mega urban regions (UN-HABITAT 2014:25) in the world with an estimated population of 13.5 million, a figure predicted to double by the year 2055 (Mubiwa \& Annegarn 2013). The City of Tshwane has nearly 3 million people (Wazimap 2017).

Within the City of Tshwane, our study focuses on two regions: Pretoria Central and Mamelodi East. Pretoria Central is the city centre, or downtown Pretoria, and consists of a cross-section of four wards (58, 60, 80 and 81) and has 100000 people (Wazimap 2017). As mentioned above, this area was the bureaucratic sphere of influence reinforcing racial superiority and political, social, spatial and economic dominance. Since 1994, this particular area of the city underwent complete demographic and sociocultural change. Residential neighbourhoods in Pretoria Central flipped in less than a decade, shifting from nearly a $100 \%$ white population in 1993-1994 to virtually a $90 \%$ black population by the year 2000. The city centre also became a catch-basin for thousands of African migrants crossing borders for security, education, refuge, employment and faith. According to the 2011 Census, $29.35 \%$ of the population in Pretoria Central are cross-border migrants while $70.65 \%$ of the population is South African-born (Wazimap 2017). This is a significant contrast to our comparative area of study in Mamelodi East where only $4.6 \%$ of the population is born outside South Africa. Our immersed experiences and co-research identified substantial Zimbabwean, Nigerian, Ethiopian, Somalian and Congolese populations in Pretoria Central, making a dynamic religious landscape. At the same time, Pretoria Central has for many years experienced a concentration of street homelessness, slumlords, so-called informal trade and commercial sex work, much more evident than in most other parts of the city (De Beer 2008:202; Smith et al. 2015).

The second region of study is Mamelodi East, which is located within Wards 15, 16, 18 and 40 of the Mamelodi Township and has 135000 people (Wazimap 2017). Mamelodi is a subsequent manifestation of the purpose of Attridgeville, namely a resettlement site for forced removals. The two townships flank the city centre, Attridgeville on the west and Mamelodi on the east. Since the 1960s, Mamelodi Township populated quickly because of the entrenched pattern of removing black residents from areas near economic access and production and white residences and dumping them outside the city, under the controlled watch of the government. Black residents were forced from places such as Marabastad and Lady Selborne to Mamelodi Township (De Beer 2008), which now is the largest black township in the City of Tshwane. Mamelodi East is representative of other townships around the City of 
Tshwane, having characteristics of more established neighbourhoods, such as Mamelodi Gardens towards the west, and densely proliferating and suddenly emerging socalled informal settlements of Mamelodi Extension 6 towards the east. Especially since 2000, informal settlements of Mamelodi East are growing at a tremendous rate in terms of density and expansion, with noticeable increase of migration from rural areas with a pursuit of employment and 'social and recreational variety' (Steyn 2009:154). Mamelodi is an area that accentuates the socio-economic and spatial disparities and inequalities of the city because of the proximate nature of the established neighbourhoods with informality, varied housing typologies and immediate juxtaposition with some of the wealthiest eastern suburbs of Pretoria, still predominantly white (Steyn 2009).

\section{Christianity's heartland}

The new centre of gravity for Christianity holds in the global South (Sanneh 2008). In Africa alone, since 1900, from the Sahara Desert to the Cape of Good Hope, Christianity swelled nearly 70 -fold from about 7 million to 470 million people (Pew Research Center's Forum on Religion and Public Life 2010). Lamin Sanneh (1983:243) contends that the phrase 'African Christianity' or 'African Churches' has often acted as a cloak for the perpetuation of the idea of the inadmissibility of Africans as a legitimate part of the wider humanity. The very status of Christianity in Africa was being undermined. Andrew Walls (2002) upholds the inherent legitimacy with deep recognition and affirmation:

The majority of Christians now belong to Africa, Asia, and Latin America. These regions will increasingly be the place where Christian decisions and Christian choices will have to be made, where creative theology will become a necessity and where the materials for constructing that theology will be such as have not been used for that purpose before. (pp. 80-81)

The focus of our research is to better understand how churches in an urbanising African context are making decisions and daily choices that creatively express lived urbanisms. The religious dimension to Africa's urban transition has been sparsely researched (Parnell \& Pieterse 2014:83) so our initial findings, though limited, are significant. The involvement of the Christian faith in the early stages of Pretoria is a thread that continues up to the present, although we will notice an indigeneity expressed in the Christianity of our contemporary urban situation. Mark Gornik, in his study of African Christianity in New York City, claims the city to be 'forward space', which provokes us to see and consider the present and future of both the church and the world (2011:loc. 120). We will consider the two regions in the City of Tshwane and notice both the prevailing informality of urbanisation and the indigeneity of churches. Even though it is likely that the churches in our study have not read or heard of Henri Lefevbre, what we uncovered in our research is that these communities of faith are actors of faith, claiming a right to the city after a history of being denied.

\section{A right to the city: From denial to citadins}

In the 1960s, as Henri Lefebvre reflected on urban realities in France, he conceptualised what has become known as the 'right to the city' approach. Lefebvre (1996:195) put forward: 'The right to the city legitimates the refusal to allow oneself to be removed from the urban reality by a discriminatory and segregative organization'. Lefebvre's writings (1996:150) call for 'a new humanism, a new praxis' in which inhabitants are enfranchised to participate in the use and production of urban space (Görgens \& Van Donk 2012:3). The right to the city was all-encompassing. It was a right to the city as a whole. Participation avails access for urban inhabitants to make or influence decisions that produce urban space. Appropriation for urban inhabitants is the right to access, to occupy and use space, and to create new space that meets human need (Lefebvre 1991:52). The right to the city has a complementary companion, the right to difference (Butler 2012:134). Lefebvre (1991:52), attuned to how space can exclude and demand uniformity, asserted that 'a new space cannot be born (produced) unless it accentuates differences'. For Lefebvre (1996:117), the urban is more or less the oeuvre of all its citizens - an evolving collective work of art embedded in everyday life (Butler 2012:143). Through much of Pretoria's history, city inhabitants who were black were completely disempowered, removed to the outside of the city, denied full participation and the full range of everyday practices, and thereby also denied a right to the city.

\section{Urban inhabitants as citadins}

Lefebvre's robust sociological and philosophical concept, however, is instructive for pressing beyond hegemony with the fundamental notion that 'all those who inhabit' the city are the actual citizens, activated with 'a transformed and renewed right to urban life' (1996:158 [italics original]). Purcell (2002:102) summarised the distinct characteristic made by Lefebvre: 'Whereas conventional enfranchisement empowers national citizens, the right to the city empowers urban inhabitants'. The everydayness, the presence, the situatedness, the ordinary rhythms, 'living out the routines of everyday life in the space of the city' (Purcell 2002:102) is the political instrument in the struggle for reappropriation and the 'means of creative and aesthetic expression' (Butler 2012:37). By integrating citizenship with inhabitant, Lefebvre (1996) argued that the right to the city:

should modify, concretize and make more practical the rights of the citizen as an urban dweller (citadin) and user of multiple services. It would affirm, on the one hand, the right of users to make known their ideas on the space and time of their activities in the urban area; it would also cover the right to the use of the centre, a privileged place, instead of being dispersed and stuck into ghettos (for workers, immigrants, the 'marginal' and even for the 'privileged'). (p. 34)

Margherita Grazioli further uncovers the ramifications of Lefebvre's integral concept of citadin, the urban inhabitant, the complete user and producer of space (Lefebvre 1996:179). 
The apartheid city and those ongoing segregation cities around the world define and demarcate what is most essential and central and what is inferior and peripheral (Grazioli 2017:12). In From citizens to citadins? Rethinking right to the city inside housing squats in Rome, Italy, Grazioli (2017:12) debunked such a binary perspective by positing that spaces that used to be marginalised as peripheral are in reality essential metropolitan tissue and 'have become a benchmark of how to transform landscape, population and social composition'.

Grazioli's research identified citadins in the housing squats of Rome. That research context is also characteristic of urbanisation in Africa, particularly acute in sub-Saharan Africa. Fast-growing cities have 'become virtually synonymous' with fast-growing communities living within precarious, slum-like conditions; $72 \%$ of the region's urban population (UNFPA 2007:16). According to the UN-HABITAT's definition (2003:243), a 'slum household' is a group of urban inhabitants dwelling under the same roof who lack one or more of the following: 'security of tenure, structural quality/durability of dwellings, access to safe water, access to sanitation facilities, sufficient-living area'.

UN-HABITAT (2014:23) forecasted that it is 'likely that the urban slum proliferation, characteristic of so many large subSaharan African cities may also become a distinct feature of its intermediate-size and smaller ones'. Edgar Pieterse (Pieterse \& Simone 2013:23), director of the African Centre for Cities, posited that African urban research and theorising about African urbanisms must be framed by and within 'the perspective of ordinary people who live in these slum conditions'. Furthermore, Pieterse puts forward that 'the shanty city is by and large the real African city' (Pieterse \& Simone 2013:21).

\section{Lived urbanisms and African urban churches: Place-making and informality}

To develop our reflections on the everyday challenges and unique features of 'urban improvisation', and, more specifically, engage how churches in the City of Tshwane embody living urbanism and claim a right to the city, we now turn to the notion of 'African urbanisms', 'southern urbanisms' or, more poetically and even prophetically, 'rogue urbanism' (Pieterse 2014; Pieterse \& Simone 2013; Swart \& De Beer 2014). AbdouMaliq Simone (2004:15) emphasised the need and opportunity to pay close attention to the potency of African cities' state of emergence, which 'has worth and value, and is a crucial aspect of Africa remaking itself'. Urbanising Africa sets its own terms, pathways and horizons with dynamism 'so unruly, unpredictable, surprising, confounding and yet, pregnant with possibility, invoking a rogue sensibility' (Pieterse \& Simone 2013:12). The call is for an ongoing community of learning and discernment to navigate the fits and starts, twists and turns in the quest to gradually understand 'the rogue intensities that mark African cityness' (Pieterse \&
Simone 2013:15). Such an audacious quest seeks to collectively uncover local knowledges, hold the complexities of the textured urbanisms, sit with the crises and embrace, although not romanticise, sustainable everyday practices (De Beer 2014; Pieterse 2014; Pieterse \& Simone 2013). Our research endeavour picks up the life rhythms, spatial usage, 'new places of congregation', of a number of urban churches in one African city (Lefebvre 1996:179; Pieterse \& Simone 2013:32; Simone 2004:15). We offer critical appreciation and query the extent to which the church is remaking itself and the city.

\section{Place-making and spatial innovations}

Place-making is the process of shaping public spaces in ways that could be liveable and meaningful for its diverse users. By applying Lefebvre's right to the city, Lepofsky and Fraser (2003:128) posit that 'place-making is participation in both the production of meaning and in the means of production of a locale'. The Project for Public Spaces advocates for placemaking to 'pay close attention to the myriad ways in which the physical, social, ecological, cultural, and even spiritual qualities of a place are intimately intertwined' (Project for Public Spaces 2009:1). Place-making holds a holistic and interconnected understanding of place and the multiplicity of factors that contribute to making place.

An underlying curiosity of ours was whether the Christian faith has the adaptive and innovative capacity to transcend or transform apartheid spaces and apartheid cities? Are there new forms of place-making emerging in formerly exclusive spaces, perhaps through how churches incarnate themselves?

We discovered, sometimes surprisingly, how local churches contributed to a sense of place-making, without it even being their intention: they often simply want an affordable space, strategically located for most of its members or potential members. Cadge and Ecklund (2007:364) describe how religion influences place-making and identity formation as migrants navigate and negotiate both selective assimilation and selective preservation.

We found this to be particularly relevant in relation to churches in Pretoria Central. Nearly 30\% of the population in this region of the city are migrants and many of the local churches are predominantly migrant churches. We gathered data for over a year and a half through participatory and supplemental processes. The participative mapping process identified 57 churches in a defined area of Pretoria Central, which is about $2 \mathrm{~km}^{2}$ in size. This region stretches from Nelson Mandela Drive in the east and Prince's Park Avenue in the west and between Jeff Masemola Street in the south and Bloed Street in the north. We identified 40 churches in a defined area of Mamelodi East, within a 1-km radius around the Mamelodi Campus of the University of Pretoria. This region is marked by a combination of more established and older township communities and vast and sprawling informal settlements.

During the mapping process, we discovered unique and innovative expressions of churches' place-making activities. 
The first innovative characteristic of several churches was an agile form to their architectural structures. To inhabit different contexts and be present in different communities, churches contextualised their particular gathering space to be congruent with the immediate built environment. We discovered in Mamelodi East, for example, the 'pop-up' nature of some churches. Peace and Mercy Church was a handmade shack dwelling from locally sourced materials of wood and corrugated metal (EpiCollect 2017). This precarious expression fits within the context where certain areas of the region experience vulnerable households popping up every day. Also in Mamelodi East, some churches are transitional or mobile, becoming visibly expressed only on Sundays when members set up tent space or simply gather at a particular open-air site. The improvisation and fluidity that mark these churches, held in common with informal settlements, not only make research more difficult, but one also can misconstrue or underestimate the actual presence of the church in a local area.

Another example of innovation, in both Mamelodi East and Pretoria Central, is the structural fluidity and the way in which churches re-purposed facilities. Carole Rakodi suggests that 'emerging Pentecostal churches and other renewalist groups have colonised secular buildings' (Parnell \& Pieterse 2014:94). Sibusisekile Day Care Centre in Mamelodi operates from Monday to Saturday, but on certain week nights and Sunday, Christians gathered as a community make the church visible and audible. In Pretoria Central, a run-of-the-mill commercial building hosted up to six different churches on Visagie Street and rented-out storefronts stacked churches side by side in several different areas of the region of study (EpiCollect 2017).

Not only were churches innovative with flexible structural forms, but what we also found striking was the way in which certain churches were proximately located as a cluster (EpiCollect 2017). This approach was more evident in Pretoria Central than in Mamelodi East. The most vivid example of clustering was 11 churches between Sophie de Bruyn and Paul Kruger Streets and Bloed and Struben Streets, which is an area of only $700 \mathrm{~m}^{2}$. Another display of a cluster is the seven churches in an area of $400 \mathrm{~m}^{2}$, between Du Toit and Sisulu Streets and Johannes Ramokhoase and Struben Streets.

\section{Informality}

A question emerging during the research process had to do with how churches relate to, or live with, informality.

Informality in cities of the global South, and urban Africa, opens up 'new territories for debate about the right to be urban' (Pieterse \& Simone 2013:44). Because of the nature of Africa city-ness coming into its own on its own terms, 'the emergent urbanism condition is amorphous and reactive to forces, akin to an amoeba that changes shape under pressure without a pre-eminent or defining character' (Pieterse \& Simone 2013:446). The agile informality, like a resilient amoeba, is notable in Marie Huchzermeyer's (2011) study of urbanisation from below.
In Cities with 'slums', Huchzermeyer (2011:15) thoroughly analysed the situation for nearly three-quarters of the subSaharan urban population and unearthed a true 'right to the city' approach, as she puts it, a fight 'from below'. Doreen Massey (2007:187), as did Huchzermeyer (2011:66), called forth a translocal, hybrid embeddedness to foster lived urbanisms from below, 'from within and afar'. Their calls come as resistance against 'cities ... not even produced for "us"' (Huchzermeyer 2011:63 italics original), or a recognition that 'the local is perpetually the victim of the global' (Massey 2007:21). When city administrators and the professional elite prioritise the interests of multinational investors, the reverberation is a utopic and myopic vision to eradicate slums (Huchzermeyer 2011). Throughout sub-Saharan Africa, funds flowed in, hasty plans were implemented and bulldozers razed vulnerable households, all under the banner for slum-free cities.

Huchzermeyer upholds the enfranchised inhabitant by envisioning a participative plan for collective and creative action to secure inhabited space, transforming the so-called slums 'from temporary and uncertain margins to permanent places in the city' (2011:66). The inhabitants remain empowered to shape their own futures.

As Huchzermeyer argued from below with 'slums' against the neoliberal and technocrat agenda, Colin Smith in his study of Nairobi argued from below with informal churches against the dominant tendency for ecclesial marginalisation. Smith (2007:260) urges for an outright refusal of the looming 'pattern of non-engagement and ecclesiastical apartheid that leaves churches mirroring the economic divisions of our urban places and failing to recognise our unity as citizens of the same City'.

A large part of Mamelodi East includes so-called informal settlements, areas that continue expanding and also those suddenly emerging (Focus Group 09/04/17). Pockets of informal trade and housing also exist in Pretoria Central. Smith's (2007) diagnostic perspective of the conceptions, attitudes and structural realities for informal settlements in Nairobi, Kenya, shed light on our urban context of study:

Just as the informal economy is the economy of the urban population which largely does not share in the benefits of urban citizenship, so informal churches need to be understood in terms of their marginalization both socio-economically and within the structures of organized religion in the city. (p. 41)

Accompanying the explosion of informality and the 'shanty city' or informal city, so-called informal religious activity or new or different expressions of religion often operate in ways that are more elusive or even hidden to the untrained eye. When we start to consider from a theological perspective Huchzermeyer's concept (2011) of 'urbanisation from below', we see elements of inhabitants shaping their own futures in community.

The presence of diverse churches spontaneously adapting to evolving urban environments, demographic changes and 
migration patterns correlates with literature, especially from Séverine Deneulin and Carole Rakodi (2011). They assert that the 'unavoidable presence and importance of religion in the lives of people in developing countries - and in most developed countries too - invite development studies and its constituent disciplines to reconsider' assumptions and trends (Deneulin \& Rakodi 2011:46). Religion influences people's sense of belonging and community and their 'construction of meanings about the world' (Deneulin \& Rakodi 2011:46).

Smith (2007:259), in reflecting on informal Pentecostal churches, often thriving in informal urban settlements, says such churches are not planted, but 'born ... in some way incarnated'. Smith's study emphasises the growth of informal Pentecostal churches amidst urban informality as legitimate expressions of an African urban Christianity, through which people construct the city, and meaning in and about the city.

In our research, we were struck by the adaptive capacity and spontaneity within changing, informal and often very vulnerable urban environments. The eruption of a multiplicity of small faith communities, early childhood centres, informal businesses and local social initiatives could be seen as innovative urbanisation from below, contributing to a local sense of place and even asserting, not necessarily in a Lefebvreian sense, a right to the city. What we could not find clear traces of, however, were signs of intentional, reflective, collective and organised actions by churches to effect lasting change and re-imagine alternative futures, in often challenging urban spaces.

\section{Empowered identity}

What we gleaned from the mapping, surveys and focus groups is the range of ways in which churches self-identify. Our process might have been more authentically collaborative had we left self-identification completely open for the churches to surface new vocabularies. The data nevertheless revealed that the type of Christianity growing in the urban context of study for the majority of the churches surveyed self-identify as Pentecostal and/or Charismatic. To provide a bit of necessary perspective on this particular category in the typology of the Christian faith, we consider the work of Allan Anderson.

Anderson's lived experience and helpful study of this expression of the Christian faith offers insight to the 'raw, incarnated, "grassroots" theology of the Spirit-type churches in Africa ... from the "underside", a people's theology" (1991:101). He deals with the dualistic disposition and simplistic oppositions often postulated through a Western lens. In doing so, he reclaims the holistic nature of African perspectives. A key aspect is that 'one's being - is inextricably tied up with one's power' (1991:64 italics original). With this operating assumption, the Holy Spirit, then, is the genuine liberating and enabling power to meet existential needs in the African world and sustain the welfare of the whole person (Anderson 1990:73; 1991:63). Anderson concludes that the 'power of the Holy Spirit liberates from the oppression of both the traditional spirit world, and Western "colonial" forms of Christianity' (1991:125).

Precisely because of the freeing power of the Holy Spirit, as Anderson uncovered, Pentecostal churches are an invigorating expression of African urban Christianity, able to inhabit and centre the margins. Lamin Sanneh (1995:61) contends that as the Gospel message was translated throughout history into the vernacular of diverse cultures, indigenous discoveries and expressions of the Christian faith brought about a 'proliferation of centres' within the church. In other words, there is a translatability of the Christian faith and no one culture can domesticate the gospel. Marthinus Daneel (1983) observed African Independent Churches' communication process of the many-sided message of liberation and puts it this way:

It is the enactment of the Gospel in day to day living, the translation of the message of liberation in the concrete, visible and physical activities of people in those fields of human experience that really matter, which constitutes credibility and inspires conviction. (pp. 59-60, [Italics original])

The churches we encountered show signs of having an empowered identity, participating creatively, even if unintentionally, in place-making and cultivating meaningmaking. In many ways, perhaps without much reflection, the churches are claiming a right to the city. And yet, one wonders if the churches have a more narrow (internal) emphasis, by which claiming space is not necessarily in the interest of the other, in solidarity with the place in which they set up church, or in a search for justice in the city. In that sense, one can indeed ask if what the churches exercise is a right to the city only as a narrow expression of self-interest, self-preservation or in the way probably intended by Lefebvre. Is there a broader (external) emphasis, with an inclination towards others, upholding the right to difference? The element of creating new space that accentuates differences and access to justice was not fully manifested.

In Pretoria Central, members represented South Africa, Malawi, Democratic Republic of Congo, Zimbabwe, Nigeria, Uganda and Kenya. Four of the churches indicated that membership was mainly South African; Grace Exploration Ministry and Christ Populate Ministries indicated that membership was 50\% South African and 50\% other African. Deeper Christian Life Ministries is 90\% Nigerian and 10\% South African. Similarly, the Redeemed Christian Church of God is $98 \%$ Nigerian and 2\% South African. The Grace of God Ministries is 98\% Congolese and 2\% other nationalities.

In Mamelodi East, it is evident that the majority of the churches covered by our survey were predominantly South African with much smaller percentages of other African countries. One has to wonder if some of the churches are manifesting the reality that ethnicity is the 'primary source of identity and the main basis for the web of social relations' (Parnell \& Pieterse 2014:89). It would then appear that there are stronger bonds to ethnicity than to the liberating power of the Holy Spirit. 


\section{Lived urbanisms and African urban churches: Every day spiritual or religious rituals}

Rituals practiced and performed in particular spaces are repositories of meaning and knowledge systems, possessing transformative agency (Pieterse \& Simone 2013:434). These particular spaces open creative agency for inhabitants to make connections, community and culture, and ultimately, the city. James K. A. Smith (2009:35) in his book, Desiring the Kingdom: Worship, Worldview and Cultural Formation, claims that embodied actors sustain ordinary, everyday practices, 'identity-forming practices' or liturgies. Furthermore, Smith shifts the centre of gravity to the heart, gut and body - 'how we imagine the world before we think about it ... finds its completion in the role of bodily practices' (Smith 2009:66 italics original). Mark Gornik's (2011:loc.853) captivating research and story-telling communicates the lived expressions of African urban Christianity in New York City where an immigrant worker:

found something about the worship of God to be so important that he made it a priority above all else ... nor did he leave his everyday life outside the doors of the church, but carried it right into the sanctuary with him. Instead of the church being an escape or refuge, it is the very place where life happens.

The story brings to light an essential characteristic of African urban Christianity. The boundary dissolves between so-called church activity and everyday life and ordinary practices. Smith's social imaginary and Gornik's observation identify the essentiality of bodily expression and everydayness. Coleman and Collins' (2000:317) work among the Quaker and Charismatic expressions of Christianity further build clarity of terms by focused attention on the 'habitual expression of religious identity and affiliation in daily life'. The individual and collective worship practices stick with people and become the arena of inspired action.

Though not an exhaustive representation of what we noticed, our co-research efforts unveiled three everyday rituals of African urban Christianity - prayer, the Bible and worship which we are presenting here as another form of lived urbanism.

\section{Prayer life}

The churches we encountered in the City of Tshwane are praying churches. Prayer is an everyday performative action. During the focus group and World Café conversations, when we asked how the church is responding to the happenings in the city and how the church is innovating, prayer was repeatedly mentioned. Our bias, even disappointment as researchers came through:

So what else do you do as a church? We've complained about what is happening in the community in the context. Are we only praying for them? Are we active? What is it that we do? (Focus Group 05/10/16); Apart from prayer, what is it that we do to help those that are unemployed? What is it? Any other thing?. (Focus Group 25/09/16)
Upon further self-criticism and deeper reflection, the churches' prayer life as a community and individuals can be a fitting practice at times. When we look back to the early urban church, we find Paul urging the urban churches in and around Corinth and Thessalonica to innovate their way in adapting existing forms of individual and collective prayer and to pray without ceasing, 'with some mixture of the spontaneous and customary' (Meeks 1983:147). Even the posture of prayer, when hearing the hymn of the Lord Jesus Christ's sacrifice and enthronement, one could imagine the urban Christians of Philippi make a public act of resistance by bending 'their knees and confess, "The Lord is Jesus Christ"' (Meeks 1983:148). More recently, in Eric Metaxas' book, Bonhoeffer: Pastor, Martyr, Prophet, Spy, Dietrich Bonhoeffer's meditation on Psalm 74 about God's revelation that the Jewish people were God's own and therefore, he took a theological stand and deliberate act of resistance whereby 'prayer was the display of the strongest possible activity' (Metaxas 2010:316-317). From what Mark Gornik observed in the African urban Christianity of New York City 'prayer situates the body in divine power, shaping a way of life in the global city' (Gornik 2011:loc. 1526).

Afe Adogame's reflections on the Celestial Church of Christ as well as Diedre Helen Crumbley's on the Church of the Lord-Aladura offer us key insights into emerging African urban Christian expressions. The vulnerabilities and vicissitudes of life in this urban world are the result of evil, an evil that is not impersonal, 'rooted in intimate social relations, expressed in the grammar of witchcraft' (Crumbley 2008:92). Crumbley further explains how there is not outright ignorance or denial of 'natural causes of human suffering, such as germs, physical trauma, or environmental catastrophe, but the ultimate causes of suffering are believed to transcend the material plane' (2008:92). Prayer is the relationally connected way to access 'heaven, and attract the attention, power and action of God, Jesus Christ, the Holy Spirit and the angelic forces against the mischievous forces that parade this world' (Adogame 2000:13). The particular positioning and selection of spoken words in the prayers matter. The holy words are spoken when facing four corners of the earth to 'serve as "spiritual ammunition" which helps in the intensification of spiritual power in the incessant "spiritual warfare"' (Adogame 2000:15-16). Gornik also noticed the bodily, African urban Christian way of life: 'Life is about prayer, and prayer is life. Prayer is theology lived, embodied, and enacted in daily life' (Gornik 2011:loc 1189).

The African urban churches of our study exemplified these elements in their practiced prayer rituals and habits. Churches have fixed and open times for prayer during the weekly rhythm of city life and during Sunday-specific worship services. The church prays in the city, for the city and on behalf of the city. One church prayed in taxi ranks while also distributing sanitary items for homeless women from Lesotho and entered Church Square with the incarnational and empowered presence of Christ (Focus Group 19/9/16). Another church holds weekly Thursday prayers with the unemployed, offering spiritual sustenance 
and support for job placement. A Pretoria Central church with the tagline - 'A place where impossibilities become possible' - had the following posters on its storefront: Prayer Rain, Lunch Hour Prophetic Encounter, Prayer and Counselling, Success \& Prayer Night. The church that is the immediate storefront neighbour to the mechanic is called 'Christ Ever Reigns Chapel International Prince of Peace Parish' and avails 'Victory Prayers' every Tuesday night and Bible Study on Thursdays. These prayer habits and rituals buttress the churches' attempts in offering financial or inkind donations to the poor, unemployed and homeless and evoke God to change the person's situation.

\section{Word of God}

Another practiced ritual is varied but regular usage of the Bible, put to effect for personal and social transformation. Similar to the urban Christians of our study, the first urban Christians gathered to listen to regular preaching and readings about the ongoing redemptive work of the incarnated, crucified, resurrected and ascended Christ. The rhetorical patterns within the Bible woo the heart, inculcate habits and change the world (cf. Meeks 1983:146-147).

We notice these patterns in different forms being expressed by the churches of Pretoria Central and Mamelodi East. One church with the tagline, 'The church where prophetic, priestly and kingly people are made' showcases a 'school of the present day dealings of God'. During the World Café, churches emphasised their responsibility to teach morals and family values, share the word of God in prisons, premarriage and marriage counselling, preach abstinence and encourage the youth. Put succinctly on the World Café table, 'the Word of God is a good solution'. Further evidence indicates that churches proclaim principles of love and forgiveness and a message of healing and restoration. Forward in Faith is evangelising at universities while Gospel Chariot Missions offer 'Get a Free Bible Degree, Apply within' (EpiCollect 2017).

Churches are using the Bible as not only a good solution for personal morality and interpersonal and familial relationships but a close companion in advocacy work. Grace Exploration Ministry indicated that they spoke on behalf of the poor, AFM Word of Life promoted human rights and justice, Creative Fountain Ministries referred refugees to professional services and Melodiya Tshwane engaged public leadership.

These claims find both historic and contemporary expression. For example, it is noteworthy that Melodiya Tshwane is one of the churches whose leadership wrote the Confession of Belhar in 1982, which according to Krüger (2003:375), 'crossed out, with one bold move, not only the post-1948 policy of apartheid, but practices, and a traditional lifestyle, of centuries'. Furthermore, Krüger (2003:376) surmised the leadership in this church vigorously engaged the sociopolitical realm with lasting positive impact whereby 'people of colour had stood up and rejected the system of their domination and exploitation'.
In Paul Gifford's review of The Bible in Africa, he notes how the leadership, decision-making and biblical exposition of one church leader triggered political transformation as empowered churches acted politically to actualise change (Gifford 2004: 399). The reading and usage of Scripture is also notable within African urban Christianity in New York City. Gornik (2011) states:

First, Scripture is an imaginative world that narrates the experiences of life. Second, it is read and heard communally to address everyday concerns and needs. Third, it is appropriated as a means of maintaining the distinct identity of transnational religious movements. Fourth, it is a basis for preaching and responding to the text. Fifth, it is received as words that have power and make commitments. (loc. 1562)

Gornik then concludes: 'Scripture is viewed as living, powerful, and relevant, especially when it inhabits the bodies of believers and communities of worship to which they belong' (Gornik 2011:loc. 1764). The Word of God animates the individuals and communities to embodied urbanisms in the City of Tshwane.

\section{World of worship}

African urban churches have various rituals within liturgy for the communal gathering of worship. According to Gornik's study: 'Liturgy works to form a way of life by enabling church members to understand the world and bodily participate in God's new world' (Gornik 2011:loc. 1180). Jehu Hanciles (2008:359) in Beyond Christendom asserts that the appropriation of music, song and dance and dynamic evocative worship within the African Pentecostal-charismatic expression is 'a crucial reason for its widespread appeal and spectacular growth'. The habits are literally sung into being and embodied in rhythmic dance.

We already noticed in Meeks' First Urban Christians that the early hymn confessed 'The Lord is Christ' and worshipped Jesus Christ as the Lord. Meeks, in order to better understand spontaneity to worship, points to Paul's exhortation for decency and order, and for eagerly desiring the Spirit. Meeks (1983:148) makes an assessment: 'The formal procedure, the known pattern, was the framework within which the individual Christian more or less spontaneously sang "his/[her]" psalm'. Adogame (2000:9) indicates: "The use of hymns/spiritual songs as a revelatory medium is central to the ethos and rhetoric of the Aladura churches as well as other indigenous African church initiatives'. The Living God reveals not only in Scripture and Creation but also in Bible songs and Spiritual songs.

Both in the World Café and focus group conversations, worship (singing, choir, youth choirs) was mentioned as forms of both innovation and competition. Lively conversation ensued to reveal two important considerations, youth agency and instigator of market competition, which we briefly address.

The churches in both regions mentioned the relevancy of song for youth, but there was unique emphasis in Mamelodi. 
Bearing in mind Adogame's insight on song being revelatory to God's active redeeming work in this world, we can make connections to Mamelodi's emphasis on youth agency in this particular ritual. A number of social ills identified immediately affect youth in Mamelodi: drugs, school dropouts, teenage pregnancy and unwanted pregnancy, abuse, child-headed homes, crime and vandalism. The church is responding to this situation by developing a youth choir. We learned from the focus group conversation in Pretoria Central that the adult choir fostered an environment conducive for relationship-building and tangibly supporting each other. Golden Gates in Mamelodi mentioned youth being directly involved in playing instruments and leading song during worship services (Focus Group Report 9/4/17) as a way to develop leadership. And finally, this ritual fosters new relational connections for role modelling and mentoring youth.

Another consideration is the way this practiced ritual becomes an instigator for market competition. A number of the co-research participants indicated that the music style played a significant factor in terms of their own church of choice and level of participation. They sifted through a selfdirected approval system on song selection, local choruses, hymn book, instrumentation or some amalgamation. And lastly, how open was the space and ethos for dance? Not only does the practiced ritual of song influence decisions about why, where and how a person joins church, it also developed what churches perceived as negative and positive forms of competition with other churches.

Churches noted the aspects of this negative form of competition. Some churches distrusted, and yet also envied other churches because their attractive music and liturgical style stole members. Another church shares a story about market value and monetary exchange for a particular musician or singer (Focus Group 29/11/16).

We identified from one church that this practiced ritual influenced positive competition around them. The AFM Word of Life church in Pretoria Central embraced the competition of their immediate context and did something about it. This church is within the densely clustered area of 11 churches. One participant of the focus group said, 'Five years ago it was only our church in this area. As we are speaking now, next door, it's a church, back, front, everywhere it's a church. ... Competition is everywhere'. Within this stage of churches rapidly being born, AFM Word of Life church still sustains 1500 people in total membership. Their tagline is catchy, 'Welcome to our church. Where everyone is somebody'. Their ministries are indicative of the aforementioned emphases.

With these details in mind, we come back to the specific approach to positive competition. Taking seriously the revelatory and celebratory role of song in living community, AFM Word of Life has their own Praise and Worship department. The department likely vets members for their character, piety and ability (Crumbley 2008:84). One participant in the focus group stated, 'At our church they are the best; they do auditions'. The focus group facilitator probed if the church needed to 'up their game' among the other 10 churches, one participant boldly declared, 'No one needs to up their game. We are already up.'

According to Gornik, 'singing, praying, testifying, and hearing the Word helps to shape a world', an urban world (2011:loc. 873). We see in the lived urbanisms among the urban Christians in the City of Tshwane how the practiced rituals not only influence individual growth but also can lead to lasting positive change, such as the Belhar Confession, provision of essential spiritual sustenance and relational connections, particularly for the youth.

\section{Conclusion}

The article briefly etched the historical connection of the City of Tshwane to the Christian faith. We then considered urbanisation and urban change in the City of Tshwane against the backdrop of African urban processes. As part of a deliberate desire to contribute to ongoing discourse pertaining to African urbanisms and southern urbanisms - but with particular emphasis to faith, religion or the church in African cities - we then considered local churches in two regions of the City of Tshwane in relation to the notions of a right to the city and lived urbanisms. Churches in Pretoria Central and Mamelodi East have claimed a right to the city, even if unintentionally, in a Lefebvreian sense, but then in the name of Jesus. They embody such a claim through an enduring presence, creative negotiation of changing and informal urban spaces, place-making from below and daily spiritual rituals.

One remains curious about the possible socio-economic and spatial impact if such churches, as expressions of a rogue urbanism, are to become more reflective and intentional about the city as place. This might be the next phase of our research: to journey more collaboratively with the same churches, unpacking the meaning and possibilities of their enduring local urban presence.

\section{Acknowledgements}

This article formed part of a collaborative research project entitled 'Religious innovation and competition amidst urban social change: a Pretoria case study'. We appreciate the following collaborative researchers for their curiosity, conversations and commitment: Eugene Baron, Nico Botha, Jacob Manyaka, Ezekiel Ntakirutimana, Wayne Renkin, Drew Smith and Cobus van Wyngaard. The project was funded by the Templeton Foundation as part of an Africawide enquiry on 'Christianity and social change in contemporary Africa'.

\section{Competing interests}

The authors declare that they have no financial or personal relationship(s) that may have inappropriately influenced them in writing this article. 


\section{Authors' contributions}

S.F.d.B. and M.R. contributed equally to the conceptualisation and writing of the article. S.F.d.B was responsible for all revisions and M.R. prepared the article for submission.

\section{References}

Adogame, A., 2000, 'Aiye loja, orun nile: The appropriation of ritual space-time in the cosmology of the Celestial Church of Christ', Journal of Religion in Africa 30(1), 3-29. https://doi.org/10.2307/1581620

Anderson, A., 1990, 'Pentecostal pneumatology and African power concepts: Continuity or change?', Missionalia 19(1), 65-74.

Anderson, A., 1991, Moya: The Holy Spirit in an African context, University of South Africa, Pretoria.

Butler, C., 2012, Henri Lefebvre: Spatial politics, everyday life and the right to the city Routledge, Oxon.

Cadge, W. \& Ecklund, E.H., 2007, 'Immigration and religion', Annual Review of Sociology 33, 359-379, viewed 25 April 2017, from http://www.jstor.org/stable/29737767

Christopher, A.J., 1983, 'From Flint to Soweto: Reflections on the colonial origins of the Apartheid City', The Royal Geographical Society 15(2), 145-149.

Christopher, A.J., 1987, 'Apartheid planning in South Africa: The case of Port Elizabeth', The Geographical Journal 153(2), 195-204. https://doi.org/10.2307/634871

Coleman, S., \& Collins, P., 2000, 'The "plain" and the "positive": Ritual, experience and aesthetics in Quakerism and Charismatic Christianity', Journal of Contemporary Religion 15(3), 317-329. https://doi.org/10.1080/713676041

Crumbley, D.H., 2008, Spirit, structure, and flesh: Gender and power in Yoruba African Instituted Churches, University of Wisconsin Press, Madison, WI ebook Collection (EBSCOhost), EBSCO Publishing, viewed 25 April 2017, from Úniv. of Nebraska(EBSCOhost), EBSCO

Daneel, M.L., 1983, 'Communication and liberation in African Independent Churches', Missionalia: Southern African Journal of Mission Studies 11(2), 57-93.

Davies, R., 1981, 'The Spatial formation of the South African city', GeoJournal supplementary issue $2,59-72$.

Demissie, F. (ed.), 2007, Postcolonial African cities: Imperial legacies and postcolonial predicaments, Routledge, Oxon

Deneulin, S. \& Rakodi, C., 2011, 'Revisiting religion: Development studies thirty years on', World Development 39(1), 45-54. https://doi.org/10.1016/j.worlddev.2010.05.007

De Beer, S., 2008, 'Contesting inner-city space: Global trends, local exclusion/s and an alternative Christian spatial praxis', Missionalia 36(2/3), 181-207.

De Beer, S., 2014, 'Whose knowledges shape our city? Advancing a community-based urban praxis', De Jure 47(2), viewed 29 April 2017, from http://repository.up. ac.za/bitstream/handle/2263/43798/DeBeer_Whose_2014.pdf?sequence=1\& isAllowed $=y$

EpiCollect, 2017, LuqiChurches, viewed 29 April 2017, from http://epicollectserver appspot.com/showMap?projectKey=ahZzfmVwaWNvbGxIY3RzZXJ2ZXItaHJkch QLEgdQcm9qZWNOGICAgM7sI48KDA

Gifford, P., 2004, 'The Bible in Africa: transactions, trajectories, and trends', Journal of Religion in Africa 34(3) 397-401, ATLA Religion Database with ATLASerials, Religion in Africa 34(3), 397-401,
EBSCOhost, viewed 01 May 2017.

Görgens, T. \& Van Donck, M., 2012, 'Exploring the potential of the "right to the city" to integrate the vision and practice of civil society in the struggle for the socio-spatial transformation of South African cities', Paper presented at the conference Strategies to overcome poverty and inequality: Towards Carnegie III, 03-07 September 2012, viewed 27 April 2017, from http://isandla.org.za/ publications/161/

Gornik, M., 2011, Word made global: Stories of African Christianity in New York City Kindle edn., Wm. B. Publishing Co., Grand Rapids, MI.

Grazioli, M., 2017, 'From citizens to citadins? Rethinking right to the city inside housing squats in Rome, Italy', Citizenship Studies 21(4), 1-16. https://doi.org/10.1080/13 621025.2017.1307607

Hanciles, J.J., 2008, Beyond Christendom: Globalization, African migration and the transformation of the West, Orbis Books, Maryknoll, NY.

Holland, J. \& Henriot, P., 1983, Social analysis: Linking faith and justice, Orbis Books, Maryknoll, NY.

Huchzermeyer, M., 2011, Cities with 'slums': From informal settlement eradication to a right to the city in Africa, UCT Press, Claremont.

Jordaan, G.J., 1989, 'Pretoria as "urbs qaudrata"', Architecture SA May/June, 1-4 viewed 18 May 2017, from http://repository.up.ac.za/bitstream/handle/2263/ 22193/ar001joa_vw.0001.pdf?sequence=1\&isAllowed=y

Krüger, J.S., 2003, Sweeping whirlwinds: A study of religious change. Reformed religion and civil religion in the city of Pretoria (-Tshwane) (1885-2000), Unisa Press, Pretoria.

Lefebvre, H., 1991, Production of space, transl. D. Nicholson-Smith, Blackwell Publishing, Oxford.

Lefebvre, H., 1996, Writings on cities, transl. and introduced by E. Kofman \& E. Lebas, Blackwell Publishers, Oxford.

Lepofsky, J. \& Fraser, J.C., 2003, 'Building community citizens: Claiming the right to place-making in the city', Urban Studies 40(1), 127-142. https://doi org/10.1080/00420980220080201
Lye, W.F., 1967, 'The Difaqane: The Mfecane in the Southern Sotho area, 1822-24', The Journal of African History 8(1), 107-131, viewed 20 May 2017, from http:// www.jstor.org/stable/180054

Lye, W.F., 1969, 'The Ndebele Kingdom south of the Limpopo River', The Journal of African History 10(1), 87-104. https://doi.org/10.1017/S0021853700009294

Mabin, A., 2015, 'Tshwane and spaces of power in South Africa', International Journal of Urban Sciences 19(1), 29-39. https://doi.org/10.1080/12265934.2014.982689

Massey, D., 2007, World city, Polity Press, Cambridge.

Meeks, W.A., 1983, The first urban Christians: The social world of the Apostle Paul, Yale University Press, New Haven, CT.

Metaxas, E., 2010, Bonhoeffer: Pastor, martyr, prophet, spy, Thomas Nelson, Nashville, TN.

Mphahlele, E., 1959, Down second avenue, Faber and Faber Limited, London.

Mubiwa, B. \& Annegarn, H., 2013, Historical spatial change in the Gauteng CityRegion, Gauteng City Region Observatory Occasional Paper 04, viewed 30 May 2017, from http://gcro.ac.za/media/reports/mubiwe_occasional paper_new.pdf

Okihiro, G.Y., 1973, 'Resistance and accommodation: baKwena-baGasechele 184252', Botswana Notes and Records 5, 104-116, viewed 20 May 2017, from http:// www.jstor.org/stable/40979382

Parnell, S. \& Pieterse, E. (eds.), 2014, Africa's urban revolution, UCT Press, Cape Town

Pew Research Center's Forum on Religion and Public Life, 2010, Tolerance and tension: Islam and Christianity in Sub-Saharan Africa, Pew Research Center, Washington, DC, viewed 28 April 2017, from http://pewforum.org/executive-summary-islamand-christianity-in-sub-saharan-africa.aspx\#footnotes

Pieterse, E., 2014, 'Epistemological practices of Southern Urbanism', Draft pape presented at the ACC Academic Seminar, 21st February, viewed 28 April 2017, from https://www.africancentreforcities.net/wp-content/uploads/2014/02/ Epistemic-practices-of-southern-urbanism-Feb-2014.pdf

Pieterse, E. \& Simone, A.M. (eds.), 2013, Rogue urbanism: Emergent African cities, Jacana Media, Aukland Park.

Project for Public Spaces, 2009, What is place-making?, viewed 30 May 2017, from https://www.pps.org/reference/what_is_placemaking/

Purcell, M., 2002, 'Excavating Lefebvre: The right to the city and its urban politics of the inhabitant', GeoJournal 58, 99-108. https://doi.org/10.1023/B:GEJO. $0000010829.62237 .8 f$

Rasmussen, R.K., 1976, 'Mzilikazi's migrations south of Limpopo, c. 1821-1827: A reassessment', Transafrican Journal of History 5(1), 52-74, viewed 14 May 2017 from http://www.jstor.org/stable/24520287

Sanneh, L., 1983, West African Christianity: The religious impact, Orbis Books, Maryknoll, NY

Sanneh, L., 1995, 'The Gospel, language and culture: The theological method in cultural analysis', International Review of Mission 74 (322/323), 47-64. https:// doi.org/10.1111/j.1758-6631.1995.tb02688.x

Sanneh, L., 2008, Disciples of all nations: Pillars of world Christianity, Oxford University Press, New York.

Simone, A.M., 2004, For the city yet to come: Changing African life in four cities, Duke University Press, Durham, NC.

Smith, C.G., 2007, 'A missiological study of Pentecostal churches in an informal settlement in Nairobi, Kenya', Unpublished DTh thesis, University of South Africa, Pretoria, viewed 20 March 2017, from http://uir.unisa.ac.za/bitstream/handle/ 10500/535/00thesis.pdf?sequence=1\&isAllowed $=y$

Smith, R.D., Ackah, W., Reddie, A. \& Tshaka, R. (eds.), 2015, Contesting post racialism: Conflicted churches in the U.S. and South Africa, University Press of Mississippi, Jackson, MS.

Steier, F., Brown, J., \& Mesquita da Silva, F., 2015, 'The World Café in action research settings', in $\mathrm{H}$. Bradbury (ed.), The SAGE handbook of action research (3rd edn.), SAGE Publications, London, viewed 29 April 2017, from http://www.theworldcafe. SAGE Publications, London, viewed 29 April 2017, from http://

Steyn, G., 2009, 'Squatting and settlement making in Mamelodi, South Africa', in T. Falola \& A.A. Usman (eds.), Movements, borders and identities in Africa, pp. 153-166, University of Rochester Press, Rochester NY.

Swart, I. \& de Beer, S., 2014, 'Doing urban public theology in South Africa: Introducing a new agenda', HTS Theological Studies 70(3), Art. \#2811, 1-14. https://doi. org/10.4102/hts.v70i3.2811

Thomlinson, R., 1990, Urbanization in post-apartheid South Africa, Unwin Hyman, London.

United Nations Human Settlements Programme (UN-HABITAT), 2003, The challenge of slums: Global report on human settlements 2003, Earthscan Publications Ltd. London, Sterling, VA, viewed 11 May 2015, from https://unhabitat.org/books/ the-challenge-of-slums-global-report-on-human-settlements-2003/

United Nations Human Settlements Programme (UN-HABITAT), 2014, The state of African cities 2014: Re-imagining sustainable urban transitions, UN-HABITAT, Nairobi, viewed 11 May 2015, from https://unhabitat.org/books/state-of-africancities-2014-re-imagining-sustainable-urban-transitions/

United Nations Population Fund (UNFPA), 2007, State of the world population 2007 Unleashing the potential of urban growth, UNFPA, New York, viewed 11 May 2015, from http://www.unfpa.org/sites/default/files/pub-pdf/695_filename_ sowp2007_eng.pdf

Wazimap, 2017, Media monitoring Africa, viewed 30 May 2017, from https:// wazimap.co.za/ 